Я. В. Бабець ${ }^{1}$, Г. О. Ушакова' ${ }^{1}$, А. І. Шевцова ${ }^{2}$ ДНІПРОПЕТРОВСЬКИЙ НАЦІОНАЛЬНИЙ УНІВЕРСИТЕТ ІМЕНІ О. ГОНЧАРА ДНІПРОПЕТРОВСЬКА МЕДИЧНА АКАДЕМІЯ²

\title{
РОЗПОДІЛ АСТРОЦИТОСПЕЦИФІЧНИХ БІЛКІВ ПРИ ДІЇ ДОКСОРУБІЦИНУ НА ЩУРІВ
}

Досліджено розподіл кальцієзв'язувального білка S-100b і гліального фібрилярного кислого білка (ГФКБ) за умов токсичної дії доксорубіцину. За допомогою конкурентного імуноферментного аналізу виявлено підвищення рівня S-100b та філаментної форми ГФКБ у структурно і функціонально різних відділах головного мозку щурів при дії доксорубіцину протягом 4 тижнів. Отримані результати показали, що доксорубіцин індукує розвиток астрогліозу в гіпокампі тварин на відміну від інших досліджуваних відділів мозку. Сумісне застосування доксорубіцину разом з антиоксидантами різної природи частково сприяє запобіганню збільшенню концентрації ГФКБ та S-100b у гіпокампі щурів. У периферичній нервовій системі серцевої тканини відзначено реципрокну зміну рівня S-100b та ГФКБ з високим ступенем кореляційного зв'язку.

КЛЮЧОВІ СЛОВА: доксорубіцин, мозок, астроглія, гліальний фібрилярний кислий білок, S-100b.

ВСТУП. Антрациклінові антибіотики є одними з найефективніших препаратів у лікуванні пухлин різної етіології, зокрема мозку [1, 11, 16]. Вплив антрациклінових препаратів на здорові тканини мозку супроводжується низкою побічних когнітивних порушень, у тому числі втратою пам'яті, схильністю до відсутності уваги, і труднощами при виконанні одночасно кількох завдань [10]. Загальна токсична дія антрациклінових цитостатиків передбачає комплекс механізмів пошкодження, направлених на розвиток окисного стресу, порушення ДНК мітохондрій і ядерної ДНК клітин, активацію апоптозу, некроз та інші шляхи ураження, що пов'язані з недостатньо вивченим метаболізмом доксорубіцину в організмі [1]. Вважають, що антрациклінові антибіотики не проникають крізь гематоенцефалічний бар'єр (ГЕБ), однак недавно було показано, що введення антрациклінів викликає збільшення периферичного фактора некрозу пухлини- $\alpha$ (TNF- $\alpha)$, який мігрує через ГЕБ і призводить до запалення та окисного стресу в головному мозку, що, найімовірніше, сприяє зниженню когнітивних функцій [5].

Західні вчені широко вивчають доставку антрациклінових кон'югатів до мозку через ускладнення перетинання антрацикліновими препаратами ГЕБ для лікування гліом, гліобластом, нейробластом та інших злоякісних новоутворень мозку $[11,16]$. Головною скла(ㄱ Я. В. Бабець, Г. О. Ушакова, А. І. Шевцова, 2015. довою гематоенцефалічного бар'єру є астроцити, які беруть участь у формуванні ГЕБ, регуляції мозкового кровотоку та його метаболічної підтримки [7]. Крім того, астроцити першими відповідають на окисний стрес та патогенні чинники, під впливом яких вони можуть змінювати свою будову та біохімічні властивості. Поведінка астроцитів характеризується розподілом ряду білків, ключовими серед яких є кальцієзв'язувальний білок S-100b та білок проміжних філаментів цитоскелета астроцитів - гліальний фібрилярний кислий білок (ГФКБ) [12, 14, 22].

S-100b в цитоплазмі існує у вигляді димеру $\beta \beta$ (21 кДа). Він бере участь у регуляції деградації білків, регулюванні компонентів цитоскелета [23], функціонуванні рецепторів [20], ферментній активації [22, 23], клітинній проліферації і диференціації [8], транскрипції [23], пересуванні клітин [23], підтриманні кальцієвого гомеостазу [23], фосфорилюванні білків [22] та ін. [14, 19, 20]. Дуже важливою функцією S-100b вважають модулювання збирання-розбирання мікротрубочок, а саме типу III проміжних філаментів астроцитів [21].

Найбільш відома функція проміжних філаментів полягає в забезпеченні механічної опори для плазматичної мембрани, де ГФКБ вступає в контакт з іншими білками, клітинами або позаклітинним матриксом, але роль ГФКБ у популяції глії мозку набагато ширша. Зміна рівня ГФКБ варіює за різних патологій (інсульт, 
мозкова травма, хвороба Альцгеймера або Паркінсона), даний білок вважають ключовим маркером астрогліозу та нейротоксичності [13], а також старіння мозку [8] та ін. [18].

Залишається багато невирішених питань щодо впливу доксорубіцину на нервові клітини мозку, а саме на астроцити. На сьогодні немає даних стосовно розподілу ГФКБ та S-100b у ЦНС і ПНС за умов дії цього цитостатика.

Отже, метою даної роботи було дослідити реакцію астроглії під впливом доксорубіцину протягом 4 тижнів та ефект цього цитостатика разом із антиоксидантами різної природи.

МЕТОДИ ДОСЛІДЖЕННЯ. Дослідження проводили на білих щурах-самцях лінії Вістар масою (210 50$)$ г. Тварин було поділено на 4 групи по 8 особин у кожній. До 1-ї групи ввійшли контрольні тварини, які отримували ін'єкції фізіологічного розчину. Щурам 2-ї групи вводили внутрішньочеревно доксорубіцин у дозі 1 мг/кг 1 раз на тиждень протягом 4 тижнів. Тварини 3-ї групи також отримували доксорубіцин за такою ж схемою, що і щури 2-ї групи, та водний розчин $1 \% \alpha$-кетоглутарату в питній воді протягом усього експерименту. Щодня тварини 3-ї групи споживали 43 мл питної рідини на 1 кг маси тіла. Щури 4-ї групи одержували внутрішньочеревно ін'єкції корвітину (Борщагівський хіміко-фармацевтичний завод, Україна) в дозі 5 мг/кг за 30-60 хв до введення доксорубіцину за вищенаведеною схемою. Після закінчення 5 тижня експерименту всіх щурів декапітували з використанням тіопенталу натрію в дозі 60 мкг/кг відповідно до вимог Міжнародної конвенції з правил гуманного поводження з дослідними тваринами.

З тканин гіпокампа, мозочка і кори великих півкуль виділяли цитозольну та філаментну фракції білків за допомогою диференційного ультрацентрифугування. Для виділення першої фракції водорозчинних та цитозольних білків тканини мозку гомогенізували у співвідношенні 1:10 в буфері А (трис-НCl - 25мМ; pH 7,4; ЕДТО - 1мМ; дитіотреітол 0,01\%, суміш протеазних інгібіторів - 2 мМ), центрифугували при 20000 g 60 хв, супернатант відокремлювали для подальшого аналізу.

Для виділення філаментної фракції осад після відокремлення мембранних білків (тритонова фракція) ресуспендували в буфері $A$, що містив 4 М сечовини, та інкубували протягом 24 год при $+4{ }^{\circ} \mathrm{C}$. Після центрифугування при 20000 g 90 хв супернатант використовували для подальшого аналізу.

В отриманих фракціях визначали концентрацію ГФКБ та S-100b за допомогою кон- курентного твердофазного імуноферментного аналізу [3] з використанням поліклональних моноспецифічних антитіл до ГФКБ (Santa Cruz Biotechnology, Inc., США) та S-100b (Sigma, США), вторинних антикролячих анти-IgG, мічених пероксидазою хрону (Sigma-Aldrich, США), та високоочищених ГФКБ (Boehringer Mannheim, Німеччина) і S-100b (Sigma, США) як стандартних калібраторів. Результати реєстрували за допомогою спектрофотометра Anthos 2010 (Фінляндія) при 492 нм.

Статистичну обробку результатів проводили за допомогою програм Statwin та Excel, використовуючи t-критерій Стьюдента. Вірогідними вважали результати, якщо $p \leq 0,05$.

РЕЗУЛЬТАТИ Й ОБГОВОРЕННЯ. У НашОМУ експерименті рівень білка S-100b, що локалізувався переважно в цитозолі астроцитів і частково виділявся у міжклітинний простір, визначали у водорозчинних цитозольних фракціях білків, отриманих з гіпокампа, таламуса, кори великих півкуль та мозочка щурів.

Введення щурам доксорубіцину в дозі 1 мг/кг маси тіла 1 раз на тиждень протягом 4 тижнів призводило до підвищення рівня кальцієзв'язувального білка S-100b у корі великих півкуль на $20 \%((3,08 \pm 0,15)$ мкг/100 мг тканини, $p \leq 0,03)$ порівняно з показником контрольних тварин $((2,51 \pm 0,14)$ мкг/100 мг тканини) (рис. 1). У гіпокампі й таламусі за умов дії доксорубіцину також спостерігали збільшення рівня S-100b на 20,5 \% з $(2,96 \pm 0,16)$ до $(3,57 \pm 0,12)$ мкг/100 мг тканини $(\mathrm{p} \leq 0,02)$ та на $26 \%$ з $(3,79 \pm 0,15)$ до $(4,77 \pm 0,43)$ мкг/100 мг тканини $(p \leq 0,08)$. У мозочку щурів вплив доксорубіцину не призводив до значущих змін рівня S-100b і склав $(3,3 \pm 0,14)$ мкг/100 мг тканини (рис. 1).

Крім важливих функцій, які відмічені у вступі, кальцієзв'язувальний білок S-100b залучається

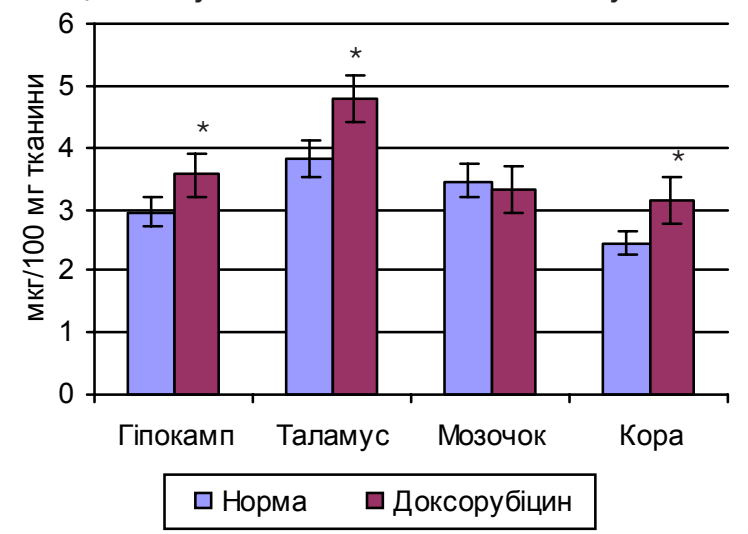

Рис. 1. Рівень кальцієзв'язувального білка S-100b у різних відділах мозку щурів за нормальних умов та при впливі доксорубіцину в дозі 1 мг/кг маси тіла 1 раз на тиждень протягом 4 тижнів $\left(n=8,{ }^{*}-p \leq 0,05\right)$. 
також до регуляції серцево-судинного розвитку, його вважають біохімічним маркером травм головного мозку після шунтування і дилатаційної кардіоміопатії [25]. Оскільки доксорубіцин може викликати кардіоміопатію $[2,6]$, ми визначили рівень S-100b у фракціях білків, отриманих із серцевого м'яза, а також у плазмі крові щурів.

Аналіз концентрації S-100b у плазмі крові щурів та відповідних екстрактах із серцевого м'яза показав, що рівень даного білка $((0,01 \pm 0,001)$ мкг/мл - у плазмі та $(0,11 \pm 0,008)$ мкг/100 мг тканини - в серці) був на порядок-два нижчим від концентрації S-100b у мозку. В серці за умов дії доксорубіцину спостерігали різке зменшення вмісту S-100b на $83 \%$ (до $(0,019 \pm 0,006)$ мкг/100 мг тканини порівняно з нормою). У плазмі крові тварин при дії доксорубіцину не відбулося вірогідних змін рівня S-100b.

Дослідження розподілу іншого білка, специфічного для проміжних філаментів цитоскелета астроцитів, - гліального фібрилярного кислого білка показали зміну співвідношення розчинної та філаментної форм даного білка при впливі доксорубіцину протягом 4 тижнів. За нормальних умов рівень розчинної форми ГФКБ у досліджуваних відділах мозку щурів склав у середньому від $(0,49 \pm 0,05)$ до $(1,91 \pm 0,4)$ мкг/100 мг тканини (рис. 2).

Ін'єкції доксорубіцину протягом 4 тижнів не призвели до вірогідних змін рівня розчинної форми ГФКБ у гіпокампі й таламусі, а в мозочку спостерігали його зменшення на 33 \% $(p<0,04)$, тоді як у корі великих півкуль відзначали тенденцію до збільшення рівня цієї форми білка на $49 \%$, але не у всіх тварин $(p \leq 0,19)$. У цитозольній фракції білків, виділеній із тканини мозку, розчинну форму ГФКБ можна отримати

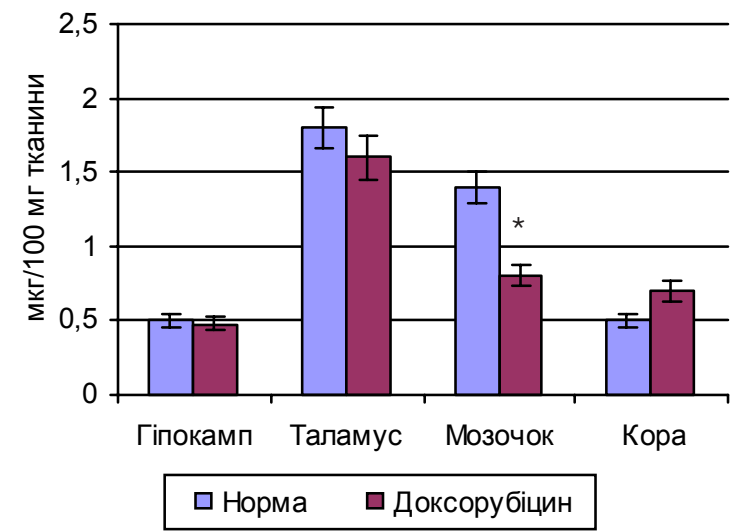

Рис. 2. Концентрація розчинної форми гліального фібрилярного кислого білка у різних відділах мозку щурів за нормальних умов та при впливі доксорубіцину в дозі 1 мг/кг маси тіла 1 раз на тиждень протягом 4 тижнів $\left(n=8,{ }^{*}-p \leq 0,05\right)$. шляхом синтезування в цитоплазмі та утворення внаслідок розбирання філаментної мережі цитоскелета астроцитів [4]. За нормальних умов рівень філаментної форми ГФКБ коливався від $(3,9 \pm 1,8)$ до $(45,4 \pm 15,1)$ мкг/ 100 мг тканини залежно від відділу мозку щурів (рис. 3). У гіпокампі відзначено збільшення концентрації філаментної форми ГФКБ на $236 \%(p<0,003)$ порівняно 3 контролем, що може бути наслідком прискорення проліферації астроцитів або біосинтезу даного білка.

У периферичній нервовій системі нейрони локалізовані в гангліях дорсальних корінців, які анатомічно оточені сателітними гліальними клітинами, що експресують ГФКБ [17]. Зокрема, ГФКБ у слідовій кількості також експресується немієлінізованими шванівськими клітинами, зірчастими клітинами печінки, підшлункової залози, подоцитами нирок [7]. При травмах, запаленні, вірусних інфекціях сателітні гліальні клітини активуються і підвищують експресію ГФКБ (що можна використовувати як маркер активації гліальних клітин ПНС) [17].

Рівень ГФКБ у серці на декілька порядків нижчий, ніж у мозку. Проте за умов впливу доксорубіцину мало місце збільшення рівня філаментної форми ГФКБ у серці на $206 \%$ $(p \leq 0,05)$ порівняно з нормою. Одночасно спостерігали підвищення рівня ГФКБ на $143 \%$ у плазмі крові щурів, які отримували доксорубіцин, але не у всіх тварин $(p \leq 0,12)$. Встановлено сильний кореляційний зв'язок $r=0,58$ в розподілі S-100b та ГФКБ у серці, де знижувався S-100b та підвищувалась філаментна форма ГФКБ.

Сумісне застосування доксорубіцину 3 антиоксидантами ( $\alpha$-кетоглутаратом ( $\alpha$ КГ) або корвітином) не призвело до нормалізації кількості S-100b у корі великих півкуль та

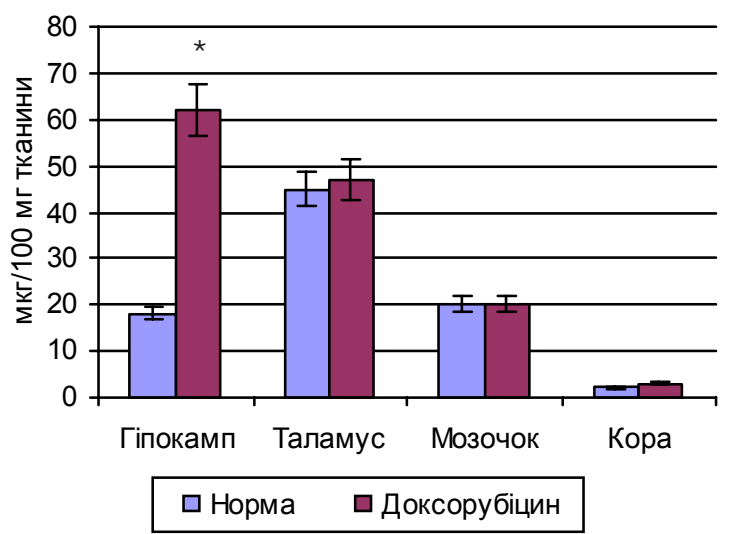

Рис. 3. Концентрація філаментної форми гліального фібрилярного кислого білка у різних відділах мозку щурів за нормальних умов та при впливі доксорубіцину в дозі 1 мг/кг маси тіла 1 раз на тиждень протягом 4 тижнів $\left(n=8,{ }^{*}-p \leq 0,05\right)$. 
гіпокампі, тоді як у таламусі спостерігали тенденцію до зниження рівня S-100b на 8 \% $(p \leq 0,12)$ до нормальних значень за умов використання $\alpha К Г$ (рис. 4).

За умов використання як корвітину, так і $\alpha$-кетоглутарату відмічено тенденцію до зниження рівня ГФКБ у гіпокампі 3 великим діапазоном похибки, але рівень філаментної форми ГФКБ ще залишався високим, як і в щурів, які отримували тільки доксорубіцин.

Застосування антиоксидантів на фоні дії доксорубіцину не призвело до покращення рівня S-100b у серцевому м'язі. Але використання $\alpha$-кетоглутарату разом із доксорубіцином спричинило зниження рівня філаментної форми ГФКБ у серцевому м'язі на $220 \%$ $(p \leq 0,04)$ порівняно з тваринами, які отримували тільки доксорубіцин, та його наближення до рівня норми, що корелювало зі зміною рівня S-100b $(r=0,88)$. Також відзначено зменшення рівня розчинної форми ГФКБ у серці на $148 \%$ $(p \leq 0,11)$ до рівня норми, але з великим діапазоном похибки, за умов використання корвітину на фоні дії доксорубіцину.

Як свідчать наведені дані, за умов доксорубіцинової токсикації відбувалася незначна активація астрогліальних кальцієзалежних механізмів захисту без деполімеризації проміжних філаментів (особливо в таламусі, який відповідає за біль та приймання всіх аферентних імпульсів, що далі направляються до кори головного мозку). Рівень філаментного ГФКБ не змінювався в таламусі, мозочку та корі великих півкуль.

Натомість при проведенні кореляційного аналізу між розподілом S-100b та ГФКБ у мозку

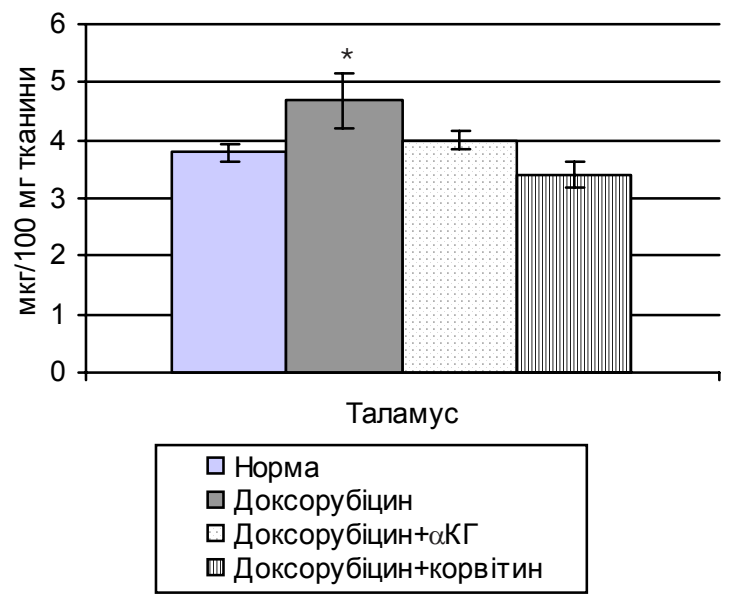

Рис. 4. Рівень кальцієзв'язувального білка S-100b у таламусі щурів за нормальних умов, при впливі доксорубіцину в дозі 1 мг/кг маси тіла 1 раз на тиждень протягом 4 тижнів та сумісному ефекті доксорубіцину й антиоксидантів різної природи ( $1 \% \alpha$-кетоглутарату в питній воді протягом 4 тижнів або корвітину в дозі 5 мг/кг за 30-60 хв до введення доксорубіцину; $n=8$, * - p $\leq 0,05$ ). піддослідних тварин було зафіксовано високий ступінь кореляційного зв'язку $(r=0,63)$ між підвищенням у гіпокампі рівня S-100b на 20,5 \% $(p \leq 0,02)$ і значним збільшенням рівня філаментного ГФКБ у гіпокампі на $236 \%$ ( $p<0,003)$, що свідчило про спорідненість процесів, характерну для високого ризику розвитку астрогліозу в гіпокампі щурів за умов впливу доксорубіцину протягом 4 тижнів. Гліальна реакція включає активацію рецепторів, зокрема Tollподібних рецепторів, факторів транскрипції (NF-кB, Nrf2, AP-1 і т. д.) та сигнальних молекул (p38MAPK, JNK, JAK/STAT3 тощо) з розвитком загального запального процесу [9]. Ефективне інгібування NF-кB та зменшення запальної реакції можна досягнути за рахунок антиоксидантних молекул, таких, як флавоноїди [9]. Отже, часткове зниження рівня ГФКБ та S-100b під впливом застосованих антиоксидантів ( $r=0,67$ при використанні корвітину) можна пояснити гальмуванням запальної реакції астроцитів за умов дії доксорубіцину.

Зменшення рівня регуляторного розчинного ГФКБ у мозочку супроводжувалося зниженням локомоторної та орієнтовно-дослідницької активності щурів на 3 і 4 тижнях експерименту, що ми визначили раніше [2]. Зниження розчинної форми ГФКБ у мозочку може бути наслідком зміни локомоторної активності тварин під впливом больового та стресового факторів доксорубіцину.

Підвищення рівня S-100b у гіпокампі й таламусі мало тісний кореляційний зв'язок ( $r=0,80$ та $r=0,47$ відповідно) 3 підвищенням рівня S-100b у корі головного мозку, що може бути результатом відповіді на больову та стресову дії доксорубіцину.

Згідно з наведеними вище даними, можна стверджувати, що цілісність ГЕБ не була порушена при дії доксорубіцину окремо та за умов сумісного застосування доксорубіцину 3 антиоксидантами, оскільки зберігався баланс між рівнем астрогліальних білків у мозку та плазмі крові. Захисна реакція астроглії в мозку стимулюється опосередковано, найімовірніше, за рахунок продукування окисних продуктів метаболізму доксорубіцину та прозапальних цитокінів під час розвитку кардіопатії, індукованої цим цитостатиком. У нашому дослідженні раніше було підтверджено, що за дози доксорубіцину 1 мг/кг маси тіла тварин протягом 4 тижнів розвивається кардіопатія [2]. Порушення роботи серця сприяє розвитку гіпоксії, за якої відбуваються втрата АТФ, порушення метаболізму глюкози і перенесення кисню, розлад роботи клітинних мембран і активація фосфоліпази, що призводить до ліполізу, 
вивільнення арахідонової кислоти, глутамату та інших токсичних нейротрансмітерів, що збільшують внутрішньоклітинний кальцій і призводять до порушення роботи нейронів мозку [15]. Отримані нами дані вказують на те, що астроглія гіпокампа і таламуса найбільш чутлива до наслідків дії доксорубіцину. Гіпокамп є структурою мозку, що найбільше піддається ушкодженню за умов дефіциту надходження кисню. Раніше було підтверджено розвиток астрогліозу в СА1-ділянці гіпокампа за умов ішемії $[19,24]$. Отримані в цьому експерименті дані показали, що тільки в гіпокампі відбуваються вірогідні зміни астроглії в напрямку розвитку астрогліозу, що, найімовірніше, $€$

\section{СПИСОК ЛІТЕРАТУРИ}

1. Бабець Я. В. Токсичні ефекти та біохімічний контроль наслідків антрациклінової терапії. Огляд / Я. В. Бабець, Г. О. Ушакова // Арх. клініч. та експерим. медицини. - 2013. - 22, № 2. - С. 242-248.

2. Зміни фізіологічних та біохімічних показників у щурів з доксорубіцин-індукованою кардіопатією на тлі застосування препаратів з антиоксидантною дією / Ю. А. Гордієнко, Я. Бакланова, М. В. Коваленко [та ін.] // Біологія тварин. - 2012. - 14, № 1-2. - С. 74-79.

3. Нго Т. Т. Иммуноферментный анализ /Т. Т. Нго, Г. М. Ленхофф, А. Яклич. - М. : Мир, 1988. - 444 с.

4. 14-3-3 affects dynamics and integrity of glial filaments by binding to phosphorylated GFAP / H. Li, Y. Guo, J. Teng [et al.] // Journal of Cell Science. 2006. - 119. - P. 4452-4461.

5. Alterations in brain antioxidant enzymes and redox proteomic identification of oxidized brain proteins induced by the anti-cancer drug adriamycin: implications for oxidative stress-mediated chemobrain / G. Joshi, C. D. Aluise, M. P. Cole [et al.] // Neuroscience. - 2010. - 166, № 3. - P. 796-807.

6. Cardioprotective effect of Vedic Guard against doxorubicin-induced cardiotoxicity in rats: A biochemical, electrocardiographic, and histopathological study / B. C. Koti, S. Nagathan, A. Vishwanathswamy [et al.] // Pharmacogn. Mag. - 2013. - 34. - P. 176-181.

7. Chia Lim M. C. Glial Fibrillary Acidic Protein Splice Variants in Hepatic Stellate Cells - Expression and Regulation / M. C. Chia Lim, G. Maubach, L. Zhuo // Mol. Cells. - 2008. - 25, № 3. - P. 376-384.

8. Cloning and Expression of the Human $\mathrm{S} 100 \mathrm{~B}$ Gene / R. J. Allore, W. C. Friend, D. O'Hanlon [et al.] // The J. of Biological Chemistry . - 1990. - 265, № 26. P. 15537-15543.

9. Colangelo A. M. Astrogliosis as a therapeutic target for neuro degenerative diseases / A. M. Colangelo, L. Alberghina, M. Papa // Neuroscience Letters. 2014. - 565, № 17. - P. 59-64.

10. Doxorubicin-induced central nervous system toxicity and protection by xanthone derivative of наслідком розвитку доксорубіциніндукованої кардіопатії.

Сумісне застосування доксорубіцину разом з антиоксидантами може частково запобігати токсичному ефекту даного цитостатика.

ВИСНОВКИ. 1. Доксорубіцинова токсикація призводить до незначної активації астрогліальних кальцієзалежних механізмів захисту без деполімеризації проміжних філаментів.

2. Дія доксорубіцину протягом 4 тижнів індукує розвиток астрогліозу в гіпокампі, що, найімовірніше, є наслідком доксорубіциніндукованої кардіопатії.

3. Антиоксиданти на фоні дії доксорубіцину частково запобігають активації астроглії.

garcinia mangostana / J. Tangpong, S. Miriyala, T. Noel [et al.] // Neuroscience. - 2011. - 23, № 175. P. 292-299.

11. Gupta R .Stage 4S Bilateral Adrenal Neuroblastoma in a Newborn / R. Gupta, T. A. Mala, P. Mathur // APSP J. Case Rep. - 2014. - 5, № 1. - P. 9-11.

12. Hassan S. Glial Fibrillary Acidic Protein (GFAP) as a Mesenchymal marker of Early Hepatic Stellate Cells Activation in Liver Fibrosis in Chronic Hepatitis C Infection / S. Hassan, S. Syed, S. I. Kehar // Pak. J. Med. Sci. - 2014. - 30, № 5. - P. 1027-1032.

13. Health assessment of gasoline and fuel oxygenate vapors: Neurotoxicity evaluation / P. J. O'Callaghan, W. C. Daughtrey, C. R. Clark [et al.] // Regul. Toxicol. Pharmacol. - 2014. - 10. - P. 1016-1024.

14. Higashino H. Immunohistochemical analysis of brain lesions using S100B and glial fibrillary acidic protein antibodies in arundic acid- (ONO-2506) treated stroke-prone spontaneously hypertensive rats $/ \mathrm{H}$. Higashino, A. Niwa, T. Satou //J. Neural Transm. 2009. - 116. - P. 1209-1219.

15. Hypothermia after cardiac arrest as a novel approach to increase survival in cardiopulmonary cerebral resuscitation: a review / $\mathrm{H}$. Soleimanpour, F. Rahmani, S. Safari [et al.] // Iran. Red. Crescent Med. J. - 2014. - 16, № 7. - P. 1-9.

16. Inoue S. Doxorubicin treatment induces tumor cell death followed by immunomodulation in a murineneuroblastomamodel / S. Inoue,Y. Setoyama, A. Odaka // Exp. Ther. Med. - 2014. - 7, № 3. - P. 703-708.

17. Marques Nascimento D. S. Satellite Glial Cells Surrounding Primary Afferent Neurons Are Activated and Proliferate during Monoarthritis in Rats: Is There a Role for ATF3? / D. S. Marques Nascimento, J. M. Castro-Lopes, F. L. Moreira Neto // PLoS One. - 2014. 9, № 9. - P. 1-9.

18. Middeldorp J. GFAP in health and disease / J. Middeldorp, E. M. Hol // Progress in Neurobiology. 2011. - 93. - P. 421-443.

19. Rajkowska G. Astrocyte pathology in major depressive disorder: insights from human postmortem 
brain tissue / G. Rajkowska, C. A. Stockmeiera // Curr. Drug Targets. - 2013. - 14, № 11. - P. 1225-1236.

20. Regulation of S100B in white adipose tissue y obesity in mice / L. B. Buckman, E. K. AndersonBaucum, A. H. Hasty [ et al.] // Landes Bioscience. 2014. - 3. - P. 215-220.

21. S-100 (alpha and beta) binding peptide (TRTK12) blocks S-100/GFAP interaction: identification of a putative S-100 target epitope within the head domain of GFAP / R. Bianchi, M. Garbuglia, M. Verzini [et al.] // Biochim. Biophys. Acta. - 1996. - 1313, № 3, Issue 11. - P. 258-267.

22. Sorci G. Association of S100B with intermediate filaments and microtubules in glial cells / G. Sorci,
A. L. Agneletti, R. Bianchi // Molecular Cell Research. 1998. - 1448, № 10, Issue 2. - P. 277-289.

23. Sorci G. S100B protein in tissue development, repair and regeneration / G. Sorci, F. Riuzzi, C. Arcuri // World J. Biol. Chem. - 2013. - 4, № 1. - P. 1-12.

24. The neuroprotective effect of 2-oxoglutarate in the experimental ischemia of hippocampus / T. N. Kovalenko, G. A. Ushakova, I. Osadchenko [et al.] // J. of Physiology and Pharmacology. - 2011. 62, № 2. - P. 239-246.

25. Tsoporis J. N. Intracellular and Extracellular Effects of S100B in the Cardiovascular Response to Disease / N. J. Tsoporis, F. Mohammadzadeh, T. G. Parker // Cardiovasc. Psychiatry Neurol. - 2010. 10. - P. 6073-6079.

Я. В. Бабец ${ }^{1}$, Г. А. Ушакова', А. И. Шевцова ${ }^{2}$ ДНЕПРОПЕТРОВСКИЙ НАЦИОНАЛЬНЫЙ УНИВЕРСИТЕТ ИМЕНИ О. ГОНЧАРА' ДНЕПРОПЕТРОВСКАЯ МЕДИЦИНСКАЯ АКАДЕМИЯ²

\section{РАСПРЕДЕЛЕНИЕ АСТРОЦИТОСПЕЦИФИЧЕСКИХ БЕЛКОВ ПРИ ДЕЙСТВИИ ДОКСОРУБИЦИНА НА КРЫС}

\section{Резюме}

Исследовано распределение кальцийсвязывающего белка S-100b и глиального фибриллярного кислого белка (ГФКБ) в условиях токсического действия доксорубицина. С помощью конкурентного иммуноферментного анализа выявлено повышение уровня S-100b и филаментной формы ГФКБ в структурно и функционально различных отделах головного мозга крыс при действии доксорубицина в течение 4 недель. Полученные результаты показали, что доксорубицин индуцирует развитие астроглиоза в гиппокампе животных в отличие от других исследуемых отделов мозга. Совместное применение доксорубицина с антиоксидантами различной природы частично способствует предотвращению увеличения концентрации ГФКБ и S-100b в гиппокампе крыс. В периферической нервной системе сердечной ткани отмечено реципрокное изменение уровня S-100b и ГФКБ с высокой степенью корреляционной связи.

КЛЮЧЕВЫЕ СЛОВА: доксорубицин, мозг, астроглия, глиальный фибриллярный кислый белок, S-100b.

Ya. V. Babets ${ }^{1}$, G. O. Ushakova ${ }^{1}$, A. I. Shevtsova ${ }^{2}$ OLES HONCHAR DNIPROPETROVSK NATIONAL UNIVERSITY ${ }^{1}$ DNIPROPETROVSK MEDICAL ACADEMY²

\section{DISTRIBUTION OF ASRTOCYTE AND SPECIFIC PROTEINS UNDER DOXORUBICIN EFFECT ON RATS}

\section{Summary}

In this study we investigated the distribution of calcium-binding protein S-100b and glial fibrillar acidic protein (GFAP) under toxic effect of doxorubicin. The competitive ELISA method showed the increasing of $S-100 b$ and filament forms GFAP in structurally and functionally different parts of the rat brain under conditions of doxorubicin action during 4 weeks. These results suggest that doxorubicin induces astrogliosis development in the hippocampus of rats, in contrast to other brain areas. Concomitant administration of doxorubicin and different nature antioxidants were indicated partial protection at the increasing of GFAP and S-100b concentration in the hippocampus of rats. The peripheral nervous system of cardiac tissue was performed reciprocal changes in the S-100b and GFAP level with a high degree of correlation.

KEY WORDS: doxorubicin, brain, astroglia, glial fibrillary acidic protein, S-100b.

Отримано 22.12.14

Адреса для листування: Я. В. Бабець, Дніпропетровський національний університет імені О. Гончара, просп. Гагаріна, 72, Дніпропетровськ, 49005, україна, e-mail: kristalxх@уandex.ru 